\title{
EMPLOYEE ATTITUDES ON TQM IMPLEMENTATION AND JOB SATISFACTION IN PUBLIC HEALTH SECTOR
}

\author{
Ivana Škarica \\ PhD, Head of Quality department, Teaching institute of public health in Rijeka, Krešimirova 52a, \\ 51000 Rijeka, Croatia; e-mail: ivanaskarica969@gmail.com \\ Ana-Marija Vrtodušić Hrgović \\ PhD, Associate Professor, University of Rijeka, Faculty of Tourism and Hospitality Management, \\ Primorska 42, P.O.B. 97, 51410 Opatija, Croatia; e-mail: anamariv@fthm.hr
}

\begin{abstract}
The quality of service in the public health sector is an essential aspect that influences patient satisfaction. Providing quality in public health sector means delivering health service in an affordable, safe and effective manner, with minimal risk and harm for patients. In other words, it means fulfilling patients' needs and surpassing their expectations. In order to provide patients with good-quality and satisfactory service, many public health organizations implement quality standards that contribute with many benefits and advantages, among which employee satisfaction stands out. The objective of the research was to evaluate the attitude of employees in public health institutes towards the dimensions of job satisfaction and their perception of the level of TQM implementation, with regard to the employees' sociodemographic characteristics. In order to achieve this objective, ANOVA was used to test the hypotheses and determine the difference between observed sociodemographic characteristics with regard to the dimensions of job satisfaction and the application of TQM principles in research. Beside that, correlation coefficient was used to test the connection between overall job satisfaction and the level of TQM implementation (overall TQM principles). The findings suggest that level of education and the length of service have a significant effect on the differences in assessments among employees, while position in the workplace affects within certain dimensions of job satisfaction, as well as within their perception of the TQM implementation. Results have also shown that there is a statistically significant relationship between job satisfaction and the level of implementation of TQM principles. The present study provides valuable guidelines for public health sector managers since the results of the research indicate the level of perception of the implementation of TQM principles and job satisfaction dimensions with which employees are the most and the least satisfied, thus pointing
\end{abstract}


out to management in public health sector institutions the areas in which certain improvement measures should be implemented. As this study focuses specifically on Institutes of Public Health, future research could be expanded to encompass other public health institutions such as hospitals and private clinics as well as other sectors.

Key words: employees, job satisfaction, public health sector, quality principles, sociodemographic characteristics, TQM

\section{INTRODUCTION}

The connection between human resources and quality is an often-researched topic, especially regarding its potential impact on organizational performance, but only recently have organisations recognized human resources (employees) as a main source of competitive advantage, profitability, success and quality. This is supported by the fact that ISO 9001, one of the most widely spread quality standards in the world, emphasises the need to ensure the engagement and empowerment of all employees in order to successfully implement and maintain a quality system in a company.

The benefits of implementing quality principles are various and have been demonstrated in many studies (Avelini Holjevac, 1996; Priede, 2012; Carlos et al., 2016; Ismyrlis, Moschidis, Tsiotras, 2015), as will be elaborated in more detail later in the paper.

Satisfied employees are one of the crucial components of any successful and longstanding company. Therefore, this paper also presents papers investigating certain dimensions that lead to employee satisfaction or dissatisfaction.

Having in mind the small number of studies dealing with this topic in the Republic of Croatia, the authors have decided to thoroughly explore the mentioned constructs.

In order to explore the connection between job satisfaction and quality principles in more detail and better understand if, and to what extent, the sociodemographic characteristics of employees affect their job satisfaction within implemented quality systems; this paper provides an extensive literature review and presents research results based on original data collected for the purpose of this research.

The study was conducted in 2019. using a questionnaire composed on the basis of several structured questionnaires and adjusted to the specific features of public health. The sample included employees from Institutes of Public Health in Croatia that are certified by ISO 9001. A total of 281 employees participated in the research and the collected data were analysed using descriptive statistics, ANOVA and Pearson correlation coefficient.

The paper proceeds as follows. First, a detailed overview of studies concerning employee job satisfaction and the implementation of quality principles are presented. Then, the used methodology is described and results, presented. The final section includes the conclusion and research limitations, as well as future research recommendations for public health management. 


\section{LITERATURE REVIEW}

Employee satisfaction is defined in many ways, but one of the most cited definitions is that of Locke (1976:1300) who stated that employee satisfaction can be defined as a "pleasurable or positive emotional state resulting from the appraisal of one's job or job experience". This definition clearly emphasizes the importance of positive surroundings as well as positive feelings about the job in order to feel satisfied. But for an employee to be satisfied, there are multiple dimensions that should be fulfilled to affect overall job satisfaction. Some of those dimensions are salary, relationship with superiors and colleagues, work conditions, advancement possibility, education, and more. Of course, depending on the individual, each of the dimensions contributes in varying degrees to overall job satisfaction.

Quality has been defined by famous quality gurus, such as Crosby, Juran, Deming and others, who have had a significant impact on the world through their numerous contributions and are considered instrumental in spreading the use of quality standards throughout the world. According to Crosby (1996:9), "quality is free", while according to Juran, quality can be defined as "fitness for use" (1999:4).

Despite different definitions, quality management systems are, according to numerous literature sources, highlighted as a necessary prerequisite for success in today's global world, due to the many advantages provided by these systems, such as a higher level of satisfaction for both employees and customers, increased profit and efficiency, improved competitiveness, enhanced sustainability, and many more. Only in recent times, however, have organizations come to realise that human resources are their most important resource and source of competitive advantage. Today it is absolutely clear that, to perform successfully, companies need professional, educated, motivated and engaged employees. In fact, ISO 9001, a basic quality standard around the world, identifies employees as one of the resources, among others, necessary for successful business performance.

Indeed, the indisputable link between employees and quality systems was the driving force behind this study, aimed at exploring the connection between those two main constructs (job satisfaction and application of TQM principles) - within public health institutions.

As in most countries, Croatian health system is comprised of public and private sector. Public sector encompasses the majority of health system with institutions like hospitals, Community health centres, and Institutes of public health. Being major institutionalized providers of activities aimed at early detection of people at risk (preventing diseases) and improving public health, Croatian Institutes of Public Health have been established in every county across the country to make health services available to everyone. Services provided by those institutions are essential for population health and, therefore, the quality of those services must be of the highest level. To ensure this, the management of the Institutes must be committed to quality, which includes the satisfaction of their employees. Having in mind stated, as well as the fact that within Croatian public health institutions, Institutes of Public Health, which present important part of the public health sector, are the most oriented ones toward quality standard implementation, they have been selected for this research.

The following section provides an overview of studies from the year 2000 onwards concerning employee job satisfaction, with special emphasize on employees in the public health sector, and 


\section{I. Škarica, A. Vrtodušić Hrgović: Employee attitudes on TQM implementation and job satisfaction... Zbornik Veleučilišta u Rijeci, Vol. 9 (2021), No. 1, pp. 187-209}

the implementation of quality principles, in general, and in the public health sector, in particular. At the end, the authors and their research results regarding the connection between job satisfaction and quality principles implementation in public health sector are presented.

Table 1. Employee job satisfaction

\begin{tabular}{|c|c|}
\hline AUTHORS & RESEARCH RESULTS \\
\hline Oshagbemi, 2000. & Job satisfaction is significantly correlated with length of service \\
\hline $\begin{array}{l}\text { Vouzas, 2004; } \\
\text { Soltani, 2003; } \\
\text { Soltani et al, 2004; } \\
\text { Fotis Vouzas, } 2007\end{array}$ & $\begin{array}{c}\text { The authors suggest placing greater emphasis on human resources than } \\
\text { on work processes, bearing in mind the significant implications that } \\
\text { this change would cause in the field of work organization, but also in } \\
\text { understanding strategic human resource management }\end{array}$ \\
\hline $\begin{array}{l}\text { Martensen \& Gronholdt, } \\
\text { 2001; } \\
\text { Matzler, Fuchs \& Schubert, } \\
\text { 2004; } \\
\text { Delina, 2020. }\end{array}$ & $\begin{array}{l}\text { Motivated and loyal employees represent value for the organization, they } \\
\text { are more committed to continuous quality improvement and to a greater } \\
\text { extent participate in the process of making decisions } \\
\text { There is a relationship between employee engagement and satisfaction }\end{array}$ \\
\hline $\begin{array}{l}\text { Chen et al., 2006; } \\
\text { Pisani, } 2009 .\end{array}$ & $\begin{array}{l}\text { Level of education influences job satisfaction } \\
\text { Longer education was associated with significantly higher levels of general } \\
\text { job satisfaction }\end{array}$ \\
\hline Matzler and Renzl, 2007. & Trust, employee satisfaction and loyalty are significantly correlated \\
\hline $\begin{array}{l}\text { Buitendach, Rothmann, } \\
\qquad 2009 .\end{array}$ & $\begin{array}{l}\text { Research results confirmed differences between job satisfaction and the } \\
\qquad \text { age and race of employees }\end{array}$ \\
\hline Unzicker, 2012. & Salary was highly correlated with job satisfaction \\
\hline Sušanj and Šulentić, 2014. & $\begin{array}{l}\text { Key factors of the communication climate are significantly correlated } \\
\text { with job satisfaction }\end{array}$ \\
\hline Kundu, Gahlawat, 2015. & Job satisfaction affects employees' intention to leave the workplace \\
\hline $\begin{array}{l}\text { Zardasht, Omed, Taha, } \\
2020 .\end{array}$ & $\begin{array}{l}\text { Rewarding and motivation are the most significant indicators of job } \\
\text { satisfaction }\end{array}$ \\
\hline $\begin{array}{l}\text { Dziuba, Ingaldi, } \\
\text { Zhuravskaya, } 2020 .\end{array}$ & $\begin{array}{l}\text { Satisfied employee devotes himself to work, performs orders better, cares } \\
\text { for others and himself }\end{array}$ \\
\hline
\end{tabular}

Source: Authors' research

Research results indicate the need to focus on human resources, since their loyalty, engagement and motivation affect their job satisfaction. In addition to loyalty and motivation, some results point to salary and communication as the most important factors of satisfaction. Furthermore, job satisfaction also affects an employee's intention to leave the job and devote to work. 
Table 2. Employee job satisfaction in the public health sector

\begin{tabular}{|c|c|}
\hline AUTHORS & RESEARCH RESULTS \\
\hline $\begin{array}{l}\text { Bodur, 2002; } \\
\text { Sur et al., 2004; } \\
\text { Seo et al., } 2004 .\end{array}$ & $\begin{array}{l}\text { Working conditions and salary are the most important factors of health } \\
\qquad \text { workers' dissatisfaction }\end{array}$ \\
\hline $\begin{array}{l}\text { Mosadeghrad, } \\
\text { Yarmohammadian, } \\
2006 .\end{array}$ & $\begin{array}{l}\text { Leadership style is significantly related to employee satisfaction, while the } \\
\text { greatest dissatisfaction was found in terms of salary, benefits and working } \\
\text { conditions }\end{array}$ \\
\hline $\begin{array}{l}\text { Selebi, Minnaar, } \\
\qquad 2007 .\end{array}$ & $\begin{array}{l}\text { All employees expressed low level of satisfaction with motivation, opportunity } \\
\text { for creativity and innovation, independence, responsibility and recognition, } \\
\text { while the main aspects of dissatisfaction were salary, working conditions, } \\
\text { promotion opportunities and insufficient recognition from superiors }\end{array}$ \\
\hline $\begin{array}{l}\text { Mosadeghrad, Ferlie } \\
\text { and Rosenberg, } 2008 .\end{array}$ & $\begin{array}{l}\text { Employees are moderately satisfied with their work and loyal to the } \\
\text { organization they work for }\end{array}$ \\
\hline Nikić et al., 2008. & $\begin{array}{l}\text { Employees are satisfied with the teamwork and work they do, while they } \\
\text { demonstrated dissatisfaction with the working conditions, amount of work } \\
\text { they do and the impact they have on the organization }\end{array}$ \\
\hline Mahmoud, 2008 & $\begin{array}{l}\text { There is a positive correlation between job satisfaction and level of education, } \\
\text { leadership, organizational commitment and support }\end{array}$ \\
\hline Ge et al., 2011. & $\begin{array}{l}\text { Employees are moderately satisfied; stress and burnout are key factors of } \\
\text { intrinsic and extrinsic job satisfaction }\end{array}$ \\
\hline Celik, Hisar, 2012. & $\begin{array}{l}\text { Job satisfaction and professionalism are significantly related. Education is a key } \\
\text { component that affects job satisfaction }\end{array}$ \\
\hline $\begin{array}{l}\text { Talasaz, Saadoldin, } \\
\text { Shakeri, } 2014 .\end{array}$ & $\begin{array}{l}\text { Job performance, job satisfaction, education and communication are directly } \\
\text { correlated }\end{array}$ \\
\hline $\begin{array}{l}\text { Asegid, Belachew, } \\
\text { Yimam, } 2014 .\end{array}$ & $\begin{array}{l}\text { Satisfaction with the work environment and group cohesion, individual } \\
\text { responsibility and work in the hospital predict the intention to change } \\
\text { jobs. In order to increase job satisfaction, it is required to make certain } \\
\text { modifications }\end{array}$ \\
\hline $\begin{array}{l}\text { Parveen, Maimani } \\
\text { and Kassim, } 2017 .\end{array}$ & $\begin{array}{l}\text { There is a statistical significance between the professional dimension and job } \\
\text { satisfaction }\end{array}$ \\
\hline
\end{tabular}

Source: Authors' research

When it comes to job satisfaction in the public health sector in addition to the previously mentioned dimensions, the authors also emphasize the connection between job satisfaction and 


\section{I. Škarica, A. Vrtodušić Hrgović: Employee attitudes on TQM implementation and job satisfaction... Zbornik Veleučilišta u Rijeci, Vol. 9 (2021), No. 1, pp. 187-209}

dimensions such as professionalism, quality of working life (stress and burnout), job performance and education.

Table 3. Implementation of TQM principles

\begin{tabular}{|c|c|}
\hline AUTHORS & RESEARCH RESULTS \\
\hline Sun, Hui, Tam, 2000. & $\begin{array}{l}\text { Employee engagement has a positive impact on TQM } \\
\text { implementation, and business improvement. Furthermore, employees } \\
\text { should be involved in TQM implementation process }\end{array}$ \\
\hline $\begin{array}{l}\text { Avelini Holjevac, Vrtodušić } \\
\text { Hrgović, } 2007 .\end{array}$ & $\begin{array}{l}\text { Business excellence of a company is determined by the quality of } \\
\text { products/services }\end{array}$ \\
\hline Avelini Holjevac, 2007. & $\begin{array}{l}\text { TQM is closely related to the business result and company's success; } \\
\text { its main goal is to fulfil all customer needs }\end{array}$ \\
\hline Kuo et al., 2009. & $\begin{array}{l}\text { The quality system according to the ISO standard contributes to } \\
\text { significant improvement of quality level and system efficiency }\end{array}$ \\
\hline Priede, 2012. & $\begin{array}{l}\text { ISO } 9001 \text { brings numerous business advantages - increased market } \\
\text { competitiveness, process improvement and conquering new markets, } \\
\text { and is one of the most often quality management systems in the world }\end{array}$ \\
\hline $\begin{array}{l}\text { Kathryn A. Boys, Anne E. } \\
\text { Wilcock, } 2014 .\end{array}$ & $\begin{array}{l}\text { Insufficient emphasis is placed on human capital. Fostering a culture } \\
\text { of quality in the organization requires time and necessary financial } \\
\text { resources to implement quality principles in the field of employment, } \\
\text { education and training }\end{array}$ \\
\hline Sadikoglu and Olcay, 2014. & $\begin{array}{l}\text { Insufficient employee involvement, commitment and awareness, } \\
\text { inadequate organizational structure and lack of resources represent } \\
\text { the main obstacles for TQM implementation }\end{array}$ \\
\hline $\begin{array}{l}\text { V. Ismyrlis et al., 2015; } \\
\text { Carlos et al.,2016. }\end{array}$ & $\begin{array}{l}\text { Certification according to the ISO } 9001 \text { has a significant impact on } \\
\text { organizational results and can be a source of competitive advantage }\end{array}$ \\
\hline $\begin{array}{l}\text { Bakotić, Rogošić, 2015; } \\
\text { Judeh, } 2011 .\end{array}$ & $\begin{array}{l}\text { Employee involvement, communication, empowerment, } \\
\text { recognition and awards, positively affect the implementation of } \\
\text { continuous improvement, factual approach to decision making } \\
\text { and process approach } \\
\text { There is a significant difference between employee involvement } \\
\text { and educational level }\end{array}$ \\
\hline $\begin{array}{l}\text { Ismyrlis, Moschidis, Tsiotras, } \\
2015 .\end{array}$ & $\begin{array}{l}\text { Leadership commitment, communication and education are the most } \\
\text { important factors for the successful operating of the quality system } \\
\text { according to ISO } 9001\end{array}$ \\
\hline
\end{tabular}

Source: Authors' research

The authors point out that introducing quality system into the service sector brings many advantages that are closely related to company success. Furthermore, the research results confirm 
other numerous advantages, ranging from increased competitiveness, and new markets and customers, to increased profits and increased customer satisfaction.

Finally, employee involvement, which includes education, communication and empowerment, positively contributes to quality system implementation.

Table 4. Implementation of TQM principles in the public health sector

\begin{tabular}{|c|c|}
\hline AUTHORS & RESEARCH RESULTS \\
\hline Abd Manaf, 2005. & $\begin{array}{l}\text { All eight principles of the quality system are applied in hospitals. } \\
\text { Physicians are the ones who support the implementation of quality } \\
\text { system to the least extent }\end{array}$ \\
\hline Wagner et al. 2006. & $\begin{array}{l}\text { Few hospitals have implemented a quality system (Netherlands } 4 \% \text {, } \\
\text { Hungary } 0 \% \text {, Finland } 3 \% \text { ). Hospitals are partly focused on quality } \\
\text { system documentation, cyclical improvement system and education, } \\
\text { but patient participation has been neglected in all three countries }\end{array}$ \\
\hline Dargahi, Rezaiian, 2007. & $\begin{array}{l}\text { A significant correlation was found between employee knowledge, } \\
\text { their behaviour, work-related activities and quality system }\end{array}$ \\
\hline $\begin{array}{l}\text { Lagrosen, Backstrom, } \\
\quad \text { Lagrosen, } 2007 .\end{array}$ & $\begin{array}{l}\text { Quality system requires leadership commitment in order to function } \\
\text { successfully. Also, it's essential to strengthen the employees' role and } \\
\text { enforce continuous improvement }\end{array}$ \\
\hline Withanachchi et al., 2007. & $\begin{array}{l}\text { Leadership, teamwork and ongoing oversight are key factors } \\
\text { that have facilitated the implementation of the 5-s TQM model. } \\
\text { Implementation of a TQM model undoubtedly improves } \\
\text { performance }\end{array}$ \\
\hline $\begin{array}{l}\text { Lazibat, Burčul and Baković, } \\
\qquad 2007 .\end{array}$ & $\begin{array}{l}\text { Only } 18 \% \text { of hospitals have been certified, while some of the } \\
\text { institutions that have implemented a quality system still do } \\
\text { not measure their patients' satisfaction level. When it comes to } \\
\text { knowledge of basic terms related to quality, results for } 4 / 5 \text { terms } \\
\text { indicated ignorance }\end{array}$ \\
\hline $\begin{array}{l}\text { Leatherman et al., 2010; } \\
\text { Zabada, Rivers and Munchus, } \\
1998 .\end{array}$ & $\begin{array}{l}\text { Implementation of quality system principles can strengthen health } \\
\text { systems }\end{array}$ \\
\hline Talib, Rahman, Azam, 2011. & $\begin{array}{l}\text { Central factors for TQM implementation in public health sector are } \\
\text { leadership commitment, teamwork, process management, customer } \\
\text { focus and their satisfaction, resource management, organizational } \\
\text { culture and behaviour, continuous improvement and education were } \\
\text { highlighted as }\end{array}$ \\
\hline Sivasankar, 2013. & $\begin{array}{c}\text { Most employees gave positive evaluations for quality system } \\
\text { implementation in hospitals }\end{array}$ \\
\hline
\end{tabular}




\begin{tabular}{|c|c|}
\hline $\begin{array}{c}\text { Stoimenova, Stoilova, Petrova, } \\
\text { 2014. }\end{array}$ & $\begin{array}{c}\text { Quality management system according to ISO 9001 contributes to } \\
\text { reducing errors, increasing operational efficiency in hospitals, and } \\
\text { increasing patients' safety }\end{array}$ \\
\hline Mosadeghrad, 2015. & $\begin{array}{c}\text { Successful implementation of TQM depends on management } \\
\text { involvement and commitment, internal and external customer focus, } \\
\text { continuous improvement implementation, education, employee } \\
\text { involvement }\end{array}$ \\
\hline Jarrett, 2016. & $\begin{array}{c}\text { The author proposes some more-appropriate methods for } \\
\text { the supervision of public health services, in particular quality } \\
\text { control methods and the need for TQM implementation }\end{array}$ \\
\hline
\end{tabular}

Source: Authors' research

The obtained results indicate that the employees of public health institutions positively evaluate the implementation of a quality system and that leadership commitments as well as the employees' commitment to quality are very important for the aforementioned.

Furthermore, the application of quality principles in the public health sector contributes to increasing efficiency and reducing errors in the workplace.

Depending on the country in which the research was conducted, the percentage of quality systems in hospitals also varies, but regardless of the application percentage, the need for greater patient participation and employee involvement is emphasized.

Table 5. TQM principles and employee job satisfaction in public health sector

\begin{tabular}{|c|c|}
\hline AUTHORS & RESEARCH RESULTS \\
\hline Ugboro, Obeng, 2000. & $\begin{array}{l}\text { Employee empowerment and increased level of job satisfaction are } \\
\text { directly related to leadership and application of TQM principles }\end{array}$ \\
\hline $\begin{array}{l}\text { Boon, Arumugam, } \\
\text { Hwa,2005. }\end{array}$ & $\begin{array}{l}\text { TQM elements significantly affect employee behaviour, especially their } \\
\text { engagement at work, commitment to organization, and job satisfaction }\end{array}$ \\
\hline Karia, Asaari, 2006. & $\begin{array}{l}\text { Continuous improvement and preventive action significantly enhance } \\
\text { job satisfaction and organizational commitment. Furthermore, } \\
\text { employee empowerment and teamwork, training and education } \\
\text { undoubtedly affect job satisfaction, involvement and commitment }\end{array}$ \\
\hline $\begin{array}{l}\text { Gregori, Napolitano et al., } \\
\qquad 2007 .\end{array}$ & $\begin{array}{l}\text { Workplace and time spent in the same workplace are related to the } \\
\text { implementation of TQM principles }\end{array}$ \\
\hline Welikala, Sohal, 2008. & $\begin{array}{l}\text { Employee empowerment is the main focus of a company with } \\
\text { implemented TQM }\end{array}$ \\
\hline Prajogo, Cooper, 2010. & TQM application can increase employee job satisfaction \\
\hline
\end{tabular}


I. Škarica, A. Vrtodušić Hrgović: Employee attitudes on TQM implementation and job satisfaction... Zbornik Veleučilišta u Rijeci, Vol. 9 (2021), No. 1, pp. 187-209

\begin{tabular}{|c|c|}
\hline Dragičević and Letunić, 2011. & $\begin{array}{c}\text { Enhancement of job satisfaction and implementation of a quality } \\
\text { system (ISO 9001) are correlated }\end{array}$ \\
\hline Arsić et al., 2012. & $\begin{array}{l}\text { Management commitment, employee education, teamwork, employee } \\
\text { compensation and performance appraisal have a positive impact on } \\
\text { employee satisfaction }\end{array}$ \\
\hline Ooi et al., 2013. & $\begin{array}{l}\text { TQM principles (leadership, process management, customer focus) } \\
\text { significantly affect the quality of employees' working life (job } \\
\text { satisfaction, commitment to the organization, involvement in the } \\
\text { work) }\end{array}$ \\
\hline Liu, Liu, 2014. & $\begin{array}{l}\text { Quality systems increase job satisfaction and a sense of a belonging, } \\
\text { and reduce workload and stress }\end{array}$ \\
\hline
\end{tabular}

Source: Authors' research

In the end, the results of the presented studies indicate a positive connection between the implementation of a quality system and employee job satisfaction. Furthermore, quality principles also positively affect employee engagement and their commitment to work, so it can be concluded that quality system implementation contributes to significant positive changes regarding employee satisfaction and more efficient hospital operation.

Although there are researches in the public health sector, there is a limited number of researches conducted in public health institutes in particular sector. Also, a limited number of studies explore the perception of satisfaction depending on various sociodemographic characteristics. Therefore, that was the motive for this research.

\section{RESEARCH METHODOLOGY}

The general objective of this study was to evaluate the attitude of employees in public health institutes towards the dimensions of job satisfaction (salary, relationship with colleagues, relationship with superior, job characteristics, advancement opportunities, acknowledgments, work conditions and education) with implemented quality systems, with regard to the employees' sociodemographic characteristics - level of education, position in the workplace and the length of service, as well as to find out is there a relationship between overall job satisfaction and level of TQM implementation (overall TQM principles).

In relation to that, four hypotheses were postulated:

H1: There is a statistically significant difference in attitudes towards job satisfaction and the application of TQM principles with regard to employees' level of education.

H2: There is a statistically significant difference in attitudes towards job satisfaction and the application of TQM principles with regard to employees' position in the workplace.

H3: There is a statistically significant difference in attitudes towards job satisfaction and the application of TQM principles with regard to employees' length of service.

H4: There is a strong correlation between overall job satisfaction and the level of implementation of TQM principles. 
The questionnaire was constructed using several structured questionnaires from domestic and foreign literature, and adapted to the specific features of public health care in Croatia. When it comes to job satisfaction, the most common dimensions were taken into account (salary, relationship with colleagues, relationship with superior, job characteristics, advancement opportunities, acknowledgments, work conditions and education) based on multiple sources (SO GO SURVEY; Pupavac, Lipovaca, Secen, 2012; Employee satisfaction survey by Macedonian State Statistical Office and others). The application of TQM (leadership, improvement, people engagement, focus on processes and customers) was measured with items from Kanji model and ISO 9001:2015. The questionnaire consisted of three parts. The first part dealt with the sociodemographic data of the employees, while the second and third part focused on job satisfaction dimensions and the application of TQM principles, respectively. At the end of the first part of the questionnaire, employees were given the opportunity to express their recommendations for improvement.

In filling out the questionnaire, the employees were asked to rate each variable on a scale from 1 to 5 ; with regard to job satisfaction -1 being "extremely dissatisfied" and 5 being "extremely satisfied" and with regard to the application of TQM principles -1 being "not in the least" and 5 being "to a very large extent".

Prior to the main research, a pilot study was conducted. Based on the collected feedback, certain minor changes were made, upon which the main research was carried out from mid-April to early June 2019.

The sample was consisted of employees from Institutes of public health that have implemented and certified ISO 9001. The approval to participate in the research was sent to general directors of Institutes and upon their written consent, employees were contacted via e-mail consisting a link to anonymous Google form survey. A total of 710 employees of Institutes of Public Health in Croatia were given the opportunity to participate in the research. The response rate was $40 \%$ ( 281 employees).

Based on obtained sociodemographic characteristics of employees, it was concluded that the majority of the population is middle-aged, non-managerial level employees with finished graduated studies, that woman prevail over man and almost $80 \%$ of the employees have between $0-20$ years of service in the Institute.

Cronbach's Alpha test was used to check the questionnaire's reliability. The results of the test indicated a satisfactory level of validity and internal consistency, thus allowing further analysis. Namely, the values of the individual dimensions were above 0.70 , while the overall reliability of two main constructs (overall job satisfaction and overall - TQM principles) in the research was above 0.90 .

Collected primary data were analysed using SPSS v.23, with descriptive statistics, ANOVA, and Pearson correlation coefficient. Arithmetic mean and standard deviation were calculated for each question, and the questions with the lowest and highest values of the arithmetic mean of the employees' answers were highlighted. 


\section{RESEARCH RESULTS}

The employees rated job satisfaction with scores ranging from 2.91 (satisfaction with recognition for a job well done) to 4.06 (satisfaction with working hours):

Table 6. Descriptive statistics - job satisfaction

\begin{tabular}{|l|c|c|}
\hline Variables & $\overline{\mathrm{x}}$ & $\mathrm{Sd}$ \\
\hline Leadership & 3,32 & 1,18 \\
\hline Relationship with colleagues & 3,88 & 1,03 \\
\hline Opportunities for future advancement & 3,02 & 1,30 \\
\hline Career progression & 3,29 & 1,28 \\
\hline Salary compared to the work done & 3,26 & 1,27 \\
\hline Teamwork & 3,53 & 1,20 \\
\hline Communication with immediate superior & 3,96 & 1,16 \\
\hline Other fees, such as transport to work & 3,46 & 1,24 \\
\hline Possibility for continuous education & 3,47 & 1,20 \\
\hline The content of the work you do & 3,94 & 1,00 \\
\hline Ability to use knowledge and skills in workplace & 3,86 & 1,02 \\
\hline Working hours & 4,06 & 1,01 \\
\hline Workload & 3,35 & 1,12 \\
\hline Availability of equipment and other resources necessary for the job & 3,30 & 1,17 \\
\hline Recognition for a job well done & 2,91 & 1,28 \\
\hline Evaluation and understanding of suggestions regarding job & 3,29 & 1,14 \\
\hline Learning opportunities within working hours & 3,21 & 1,25 \\
\hline General job satisfaction & 3,73 & 0,98 \\
\hline
\end{tabular}

Source: Authors' research

The standard deviation is greater than 1 for all variables, so in those cases the scatter of the data is greater than the arithmetic mean. Besides working hours, employees were very satisfied with communication with immediate superior, the content of the work they do, relationship with colleagues and ability to use knowledge and skills in, while some additional activities can be focused on opportunities for future advancement in business, learning opportunities within working hours, salary compared to the work done, career progression in organization, evaluation and understanding of suggestions regarding job, availability of equipment and other resources necessary for the job and leadership.

Employees rated general job satisfaction as satisfactory (3.73; SD 0.98), so it can be concluded that employees are satisfied with their jobs. But despite this relatively good score, it is obvious that there is still room for certain improvements which could help to achieve a higher level of employee satisfaction. 
Furthermore, the employees rated the application of TQM principles with scores ranging from 2.77 (active use of the employee proposal collection system) to 4.04 (management's responsibility for quality in the organization):

Table 7. Descriptive statistics - TQM principles

\begin{tabular}{|l|c|c|}
\hline Variables & $\bar{x}$ & Sd \\
\hline Management's responsibility for quality in the organization & 4,04 & 1,02 \\
\hline $\begin{array}{l}\text { Participation of heads of organizational units in the process of quality } \\
\text { improvement }\end{array}$ & 3,60 & 1,08 \\
\hline Leadership and employee motivation & 2,93 & 1,19 \\
\hline Making decision based on facts & 3,07 & 1,20 \\
\hline Providing feedback about employees results & 3,13 & 1,20 \\
\hline $\begin{array}{l}\text { Availability of funds required to meet the objectives of organizational } \\
\text { units }\end{array}$ & 3,23 & 1,12 \\
\hline Encouraging business communication through teamwork & 3,19 & 1,19 \\
\hline Finding solutions as a team & 3,26 & 1,17 \\
\hline Manager support in quality improvement & 2,84 & 1,17 \\
\hline Information you receive about the results of your work & 3,02 & 1,20 \\
\hline Resolving and processing complaints & 3,23 & 1,19 \\
\hline Customer satisfaction assessment & 3,33 & 1,11 \\
\hline Defining current and future requirement of service users & 3,39 & 1,05 \\
\hline Use of information obtained from users to improve the service & 3,52 & 1,08 \\
\hline Contribution of the internal audit results to the improvement of & 3,55 & 1,14 \\
\hline quality management system in the organization & 3,35 & 1,10 \\
\hline Existence of a continuous improvement culture & 2,77 & 1,23 \\
\hline Active use of the employee proposal collection system & 3,23 & 1,17 \\
\hline Implementing improved service after detected error & 3,20 & 1,19 \\
\hline Use of data from complaints to improve quality and resolve issues
\end{tabular}

$$
\text { Source: Authors' research }
$$

The standard deviation is greater than 1 for all variables, so in those cases the scatter of the data is greater than the arithmetic mean. In addition to the stated values, employees have indicated the need for enhancement regarding manager support in quality improvement, leadership and employee motivation, information they receive about the results of their work, and other variables, while the use of information obtained from users to improve the service, contribution of the internal audit results to the improvement of quality management system in the organization and participation of heads of organizational units in the process of quality improvement have been rated with high level of application.

A small number of questions in the questionnaire were intended exclusively for manager-level employees, because to answer to them, certain knowledge and information are required that not 
all employees possess. Manager-level employees rated these variables with scores ranging from 3.51; SD 0.91 (measuring process results) to 3.72; SD 0.79 (defining processes according to user requirements). Furthermore, integration of quality principles into operational management (mean 3.57, SD 0.95) was rated little lower than clearly defined quality objectives (mean 3.70, SD 1.05). The standard deviation for only one variable is greater than 1, i.e., out of a total of four variables, three of them have a standard deviation less than 1 , which in these cases indicates a small scatter of data from the arithmetic mean.

Table 8. Quality principles' application from the managerial aspect

\begin{tabular}{|c|c|c|c|c|c|}
\hline \multicolumn{2}{|c|}{ Variables } & $\mathrm{N}$ & $\%$ & $\overline{\mathrm{x}}$ & $\mathrm{Sd}$ \\
\hline $\begin{array}{c}\text { Integration of quality principles into } \\
\text { operational management }\end{array}$ & Total & 53 & $100,0 \%$ & 3,57 & 0,95 \\
\hline Clearly defined quality objectives & Total & 53 & $100,0 \%$ & 3,70 & 1,05 \\
\hline $\begin{array}{c}\text { Processes defined according to users } \\
\text { requirements }\end{array}$ & Total & 53 & $100,0 \%$ & 3,72 & 0,79 \\
\hline Measuring process results & Total & 53 & $100,0 \%$ & 3,51 & 0,91 \\
\hline
\end{tabular}

Source: Authors' research

The employees were given the opportunity to put forward suggestions for improvement. The majority of the 26 collected suggestions referred to the need for better organization of work, better information flow, and improved communication within the Institutes. Part of the suggestions also referred to reducing the workload and improving interpersonal relationships.

As mentioned above, the collected primary data were analysed using ANOVA and correlation coefficient. The test results for the observed sociodemographic indicators with regard to the observed dimensions of job satisfaction and the application of TQM principles using ANOVA are presented below (Table 9).

For the purpose of this research, the employees' educational level was divided into nine classes: primary education, secondary school education lasting less than three years, secondary school education lasting less than four years, secondary school education lasting four or more years, undergraduate university/professional study, graduate university/professional study, postgraduate specialist study, postgraduate scientific master's study and postgraduate university doctoral study.

The employees' position in the workplace was defined using several categories: top management, head of the organizational unit (e.g. service), head of the sub-unit, and other employees, while regarding their length of service they were divided into 5 categories: 0-10 years, 11-20 years, 21-30 years, 31-40 years and more than 40 years. The obtained results regarding stated are shown in Table 9. 
I. Škarica, A. Vrtodušić Hrgović: Employee attitudes on TQM implementation and job satisfaction... Zbornik Veleučilišta u Rijeci, Vol. 9 (2021), No. 1, pp. 187-209

Table 9. Results of ANOVA test

\begin{tabular}{|c|c|c|c|c|c|c|c|c|c|}
\hline Variables & $\mathrm{N}$ & $\bar{x}$ & Sd & p1 & $\mathrm{F} 1$ & p2 & F2 & p3 & F3 \\
\hline Salary & 281 & 3.3577 & 1.12330 & 0.000 & 8,034 & 0.159 & 1,742 & 0.000 & 15,530 \\
\hline $\begin{array}{l}\text { Relationship with } \\
\text { colleagues }\end{array}$ & 281 & 3.7028 & 1.03758 & 0.136 & 1,563 & 0.130 & 1,896 & 0.000 & 6,573 \\
\hline $\begin{array}{l}\text { Relationship with } \\
\text { superiors }\end{array}$ & 281 & 3.6388 & 1.04298 & 0.000 & 3,904 & 0.087 & 2,211 & 0.000 & 11,125 \\
\hline Job characteristics & 281 & 3.8986 & .94086 & 0.028 & 2,196 & 0.186 & 1,615 & 0.012 & 3,261 \\
\hline $\begin{array}{l}\text { Advancement } \\
\text { opportunities }\end{array}$ & 281 & 3.1530 & 1.23335 & 0.000 & 3,640 & 0.01 & 5,517 & 0.000 & 8,488 \\
\hline Acknowledgments & 281 & 3.1014 & 1.14620 & 0.000 & 4,935 & 0.013 & 3,666 & 0.000 & 10,452 \\
\hline Work conditions & 281 & 3.5694 & .89799 & 0.000 & 6,635 & 0.020 & 3,327 & 0.000 & 9,815 \\
\hline Education & 281 & 3.3416 & 1.11276 & 0.001 & 3,339 & 0.042 & 2,772 & 0.001 & 5,074 \\
\hline $\begin{array}{l}\text { General job } \\
\text { satisfaction }\end{array}$ & 281 & 3.7295 & .98460 & 0.000 & 4,019 & 0.077 & 2,310 & 0.000 & 7,888 \\
\hline $\begin{array}{l}\text { Overall job } \\
\text { satisfaction }\end{array}$ & 281 & 3.4762 & .88212 & 0.000 & 4,710 & 0.017 & 3,440 & 0.000 & 12,163 \\
\hline Leadership & 281 & 4110 & .90441 & 000 & 4,353 & 0.077 & 2,301 & 0.000 & 7,766 \\
\hline $\begin{array}{l}\text { Engagement of } \\
\text { people }\end{array}$ & 281 & 3.1127 & 1.04576 & 0.000 & 4,844 & 0.004 & 4,618 & 0.000 & 9,834 \\
\hline $\begin{array}{c}\text { Focus on processes } \\
\text { and customers }\end{array}$ & 281 & 3.2909 & 1.00828 & 0.000 & 5,493 & 0.023 & 3,222 & 0.001 & 5,005 \\
\hline Improvement & 281 & 3.2826 & 1.01151 & 0.000 & 5,558 & 0.013 & 3,652 & 0.000 & 6,387 \\
\hline $\begin{array}{c}\text { Quality principles } \\
\text { application from the } \\
\text { managerial aspect }\end{array}$ & 53 & 3.6226 & .78695 & 0.635 & 642 & 0.070 & 2,809 & 0.523 & ,813 \\
\hline $\begin{array}{l}\text { Overall - TQM } \\
\text { principles }\end{array}$ & 281 & 3.2577 & 94317 & 0.000 & 5,643 & 0.011 & 3,786 & 0.000 & 8,297 \\
\hline
\end{tabular}

p1, F1 - Results of ANOVA test with regard to educational level

p2, F2 - Results of ANOVA test with regard to position in the workplace

p3, F3 - Results of ANOVA test with regard to length of service

\section{Source: Authors' research}

With a 95\% ( $p<0.05)$ confidence level, it can be stated that there is a statistically significant difference in the average scores for salaries, relationship with superior, job characteristics, advancement opportunities, acknowledgements, work conditions, education, general and overall job satisfaction, leadership, engagement of people, focus on processes and customers, improvement, and overall -TQM principles, when it comes to employees' educational level and length of service. Relationship with colleagues also demonstrated a statistically significant difference in the average scores when it comes to length of service, but not when it comes to educational level. 
When it comes to the position held in the workplace, there is a statistically significant difference in average scores for previously mentioned variables, except when it comes to average scores for salary, relationship with colleagues, relationship with superiors, job characteristics, general job satisfaction, leadership, and quality principles application from the managerial aspect.

Therefore, we can state that the hypothesis $\mathrm{H} 1$ and $\mathrm{H} 3$ are confirmed, while $\mathrm{H} 2$ is partially confirmed.

Since obtained results demonstrated statistically significant results, Tukey HSD post hoc test was used to examine which arithmetic means differed significantly from one another:

- When it comes to education level, the results pointed out that for overall-TQM principles, focus on processes and customers, improvement, engagement of people and leadership, there is a statistically significant difference between employees with primary education and employees with completed secondary education/ undergraduate, graduate and postgraduate study, while for the remaining variables there is a difference between employees with secondary education and employees with a graduate degree study / postgraduate study $(\mathrm{p}<0.05)$

- When it comes to position in the workplace, the results pointed out that for overall-TQM principles, focus on processes and customers, improvement, advancement opportunities, recognition, work conditions and engagement of people there is a statistically significant difference between other employees and the head of the organizational unit/head of the sub-unit $(p<0.05)$

- When it comes to length of service, the results pointed out that there is a statistically significant difference for all variables $(p<0.05)$ between employees employed from $0-10$ years and the ones with longer length of service (11-20 years, 21-30 years and 31-40 years)

In order to examine the interrelationship between two variables - overall job satisfaction and level of implementation - overall TQM principles, a correlation was conducted and results presented in table 10:

Table 10. Results of Pearson correlation coefficient

\begin{tabular}{|c|c|c|}
\hline \multicolumn{2}{|c|}{} & Overall - TQM principles \\
\hline \multirow{2}{*}{ Overall job satisfaction } & $r$ &, $862^{* *}$ \\
\cline { 2 - 3 } & $\mathrm{p}$ &, 000 \\
\cline { 2 - 3 } & $\mathrm{N}$ & 281 \\
\hline \multirow{2}{*}{$* *$ Correlationn is significant at the 0.01 level } \\
\hline
\end{tabular}

Source: Authors' research

From the results shown in table 10., regarding the level of Pearson's correlation coefficient for overall job satisfaction and the level of implementation of overall TQM principles, it can be concluded 
that there is a correlation of strong intensity $(r=0,862 ; p<0,01)$, i.e., it indicates that the observed dimensions are very positively related and that hypothesis $\mathrm{H} 4$ is confirmed.

Data presented in Table 11 summarise the hypotheses testing in this research:

Table 11. Summary of hypotheses testing

\begin{tabular}{|c|c|c|c|}
\hline & HYPOTHESIS & METHOD & RESULTS \\
\hline $\mathrm{H} 1$ & $\begin{array}{l}\text { There is a statistically significant difference in attitudes towards job } \\
\text { satisfaction and the application of TQM principles with regard to } \\
\text { employees' level of education. }\end{array}$ & ANOVA & Confirmed \\
\hline $\mathrm{H} 2$ & $\begin{array}{l}\text { There is a statistically significant difference in attitudes towards job } \\
\text { satisfaction and the application of TQM principles with regard to } \\
\text { employees' position in the workplace. }\end{array}$ & ANOVA & $\begin{array}{l}\text { Partially } \\
\text { confirmed }\end{array}$ \\
\hline $\mathrm{H} 3$ & $\begin{array}{l}\text { There is a statistically significant difference in attitudes towards job } \\
\text { satisfaction and the application of TQM principles with regard to } \\
\text { employees' length of service. }\end{array}$ & ANOVA & Confirmed \\
\hline $\mathrm{H} 4$ & $\begin{array}{l}\text { There is a strong correlation between overall job satisfaction and the level } \\
\text { of implementation of TQM principles. }\end{array}$ & $\begin{array}{l}\text { Pearson } \\
\text { correlation }\end{array}$ & Confirmed \\
\hline
\end{tabular}

Source: Authors' research

The results of tested differences in the ratings of the observed constructs with regard to the selected sociodemographic characteristics demonstrate that education level and length of service significantly affect the differences in the employees' assessments. Furthermore, the results of conducted Pearson correlation indicate on correlation of strong intensity between the observed constructs.

The obtained results can be compared with the results of Judeh (2011), Mahmoud (2008) and Chen et al. (2006) who argued that level of education affects job satisfaction, while the study by Oshagbemi (2000) confirmed that the length of service is related to job satisfaction. The research results of Pisani (2009) demonstrate that a higher educational level was associated with significantly higher levels of job satisfaction.

Results obtained by Pearson's correlation can be compared to the ones by Mosadeghrad (2015) and Boon, Armugam and Hwa (2005) who confirmed the correlation between the TQM principles and job satisfaction dimensions.

\section{CONCLUSION AND DISCUSSION}

In today's global market, the quality of a service is pivotal, regardless of whether it is provided by a public or private institution, or in a developed or undeveloped country. Some sectors, such as public health sector, are particularly affected by strict requirements and higher expectations because their services concern human lives and the slightest mistake (insufficient quality) can be fatal. 
The above implies that if the necessary level of quality is to be achieved, many preconditions need to be fulfilled, one of the most important ones being satisfied employees. Therefore, this study has integrated all the above stated - quality standards, job satisfaction and the public health sector - with the aim of exploring the attitudes of employees in public health institutes towards the observed dimensions of job satisfaction with the implemented quality system, with regards to employees' sociodemographic characteristics.

Cronbach's Alpha test results indicated a satisfactory level of validity and internal consistency. Values for individual dimensions were above 0.70 , while the overall reliability of two main constructs in the research was above 0.90 .

Descriptive statistics pointed out that employees rated job satisfaction with scores ranging from 2.91 (satisfaction with recognition for a job well done) to 4.06 (satisfaction with working hours), while general job satisfaction was rated as very good (3.73).

Employees rated the application of TQM principles with scores ranging from 2.77 (active use of the employee proposal collection system) to 4.04 (management's responsibility for quality in the organization), while manager-level employees gave scores ranging from 3.51 (measuring process results) to 3.72 (defining processes according to user requirements) in response to four extra questions that were relevant for that particular group of respondents. Even though management's responsibility for quality achieved the highest rate, management support and leadership have been rated lower, which indicates the area for improvement regarding management role that is crucial in both aspects.

Lower results for job satisfaction and TQM principles' application indicate the need for improvements on relation between superiors and employees. One of the measures can be focused on fostering employee recognition. If employees receive recognition for a job well done, it could encourage them to participate in proposal collection system.

The results of ANOVA indicated that educational level and length of service significantly affect the differences in assessment of the employees in all dimensions of job satisfaction and all analysed TQM principles., while position in the workplace affects the differences in assessment of the employees when it comes to certain dimensions (advancement opportunities, acknowledgements, work conditions, education, overall job satisfaction, engagement of people, focus on processes and customers, improvement and overall TQM principles). These results are consistent with those of other authors (Judeh, 2011; Mahmoud, 2008; Chen et al., 2006; Oshagbemi, 2000; Pisani, 2009).

Based on the above, hypotheses $\mathrm{H} 2$ is partially confirmed, while $\mathrm{H} 1$ and $\mathrm{H} 3$ are confirmed, meaning there is a statistically significant difference in attitudes towards the observed dimensions of job satisfaction and the application of TQM principles among employees, with regard to stated sociodemographic characteristics.

The results of Pearson's correlation coefficient indicate that overall job satisfaction and the level of implementation of TQM principles are very positively related, which confirms hypothesis $\mathrm{H} 4$. 
It should be noted that this study has certain limitations. First, the research was conducted within institutes that have implemented and certified ISO 9001 and even though the collected sample was representative, future research should include other public health institutes or even other healthcare institutions.

Second, studies dealing with this topic were almost entirely from foreign literature sources, so there was limited comparison with similar studies in the domestic literature.

Also, some of the employees' sociodemographic data was used in analysis (length of service, position in the workplace and education level).

Overall, this paper makes valuable contributions to managers in public health sector. The results of the research presented in this paper can be used as guidelines for the management of other Institutes of public health, and generally - public and private health institutions in the Republic of Croatia and wider, and can also provide guidance for further research of key dimensions of employee satisfaction within implemented quality systems. Having in mind the obtained results, especially the fact that TQM principles are highly connected to employees' satisfaction, public health management should definitely take a step towards implementation of quality standards. Even though this analysis has shown that in general, employees in public health sector are satisfied with their job, it is important not to forget that there is always room for improvement; not only in work processes, but in every sphere of work life, because satisfied employees are the guarantors of quality and the strongest competitive advantage.

\section{REFERENCES}

Abd Manaf, N. H. (2005) "Quality mangement in Malaysian public health care", International Journal of Health Care Quality Assuranse, 18(3), p. 204-216. https://doi.org/10.1108/09526860510594767

Arsić, M., Nikolić, Đ., Živković, Ž., Urošević, S., Mihajlović, I. (2012) „The effect of TQM on employee loyalty in transition economy, Serbia", Total Quality Management \& Business Excellence, 23(5-6), p. 719-729. https://doi.org/10.1080/1 4783363.2012.669930

Asegid, A., Belachew, T., Yimam, E. (2014) „Factors influencing job satisfaction and anticipated turnover amongnurses in Sidama zone public health facilities", South Etiopia, Nursing Research and Practice, 1-26. https://doi. org/10.1155/2014/909768

Avelini Holjevac, I. (2007) Menadžment kvalitete i poslovna izvrsnost, Zbornik radova 8. Međunarodnog simpozija o kvaliteti Hrvatskog društva menadžera kvalitete, Baška.

Avelini Holjevac, I., Vrtodušić Hrgović, A. (2008) Kontroling i menadžment kvalitete, 9. Simpozij o kvaliteti Hrvatskog društva menadžera kvalitete, Plitvice.

Bakotić, D., Rogošić, A. (2015). Employee involvement as a key determinant of core quality management practice, Total Quality Mangement and Business Excellence, 28(11-12), str. 1-18. https://doi.org/10.1080/14783363.2015.1094369

Bodur, S. (2002) "Job satisfaction of health care staff employed at health centres in Turkey“; Occupational Medicine, 52(6), p. 353-355. https://doi.org/10.1093/occmed/52.6.353

Boon, O. I, Arumugam, V., Hwa, T. S. (2005) „Does soft TQM predict employees' attitudes?",The TQM Magazine, 17(3), p. 279 - 289. https://doi.org/10.1108/09544780510594243

Bos, J., Donders, N., Bouwman-Brouwer, K., van der Gulden, J. (2011) „Determinants of job satisfaction in four age groups: university employees' point of view“, Tijdschrift voor toegepaste Arbowetenschap, 1, p. 14-21 
Boys, K. A., Wilcock, A. E. (2014) „Improving integration of human resources into quality management system standards", International Journal of Quality \& Reliability Management, 31(7), p. 738 - 750. https://doi.org/10.1108/ IJQRM-07-2012-0107

Buitendach, J. H., Rothmann, S. (2009) „The validation of the Minnesota Job Satisfaction questionnaire in selected organizations in South Africa", SA Journal of Human Resource Management, 7(1), p.1-8. https://doi.org/ 10.4102/ sajhrm.v7i1.183

Candido, C. J. F., Coelho, L., Peixinho, R.M.T. (2016) „The financial impact of withdrawn ISO 9001 certificate“, International Journal of Operations \& Production Management, 36(1), p. 23-41. https://doi.org/10.1108/IJOPM-11-2014-0540

Çelik, S., Hisar, F. (2012) „The influence of the professionalism behaviour of nurses working in health institutions on job satisfaction", International Journal of Nursing Practice, 18, p. 180-187. https://doi.org/10.1111/j.1440172X.2012.02019.x

Chen, S., Yang, C., Shiau, J., Wang, H. (2006) „The development of an employee satisfaction model for higher education“, The TQM Magazine, 18(5), p. 484-500. https://doi.org/10.1108/09544780610685467

Crosby, P.B. (1996) Kvaliteta je besplatna. Privredni vjesnik/Binoza Press, Zagreb

Dargahi, H., Rezaiian, M. (2007) „Correlation between knowledge, attitude and performance of the employees with quality assurance system implementation by the employers", Iranian Journal of Public Health, 36(3), p. 45-51

Delina, G. (2020) „A study on the interrelationships between employee engagement, employee engegement initiatives and job satisfaction", International Journal of Business Excellence, 20(2), p. 242-268. https://doi.org/10.1504/ IJBEX.2020.105355

Dragičević, M., Letunić, S. (2011) "The influence of international standard ISO 9001 implementation on the human resource management in hotels", Annals and Proceedings of DAAAM International Symposium, 22(1), p.265-266

Dziuba, S. T., Ingaldi, M., Zhuravskaya, M. (2020) „Employees' job satisfaction and their work performance as elements influencing work safety", System Safety: Human -Technical Facility - Environment, 2(1), p.18-25. https://doi. org/10.2478/czoto-2020-0003

Republic of Macedonia State Statistical Office (2009) EMPLOYEE SATISFACTION SURVEY, Basic survey information. Macedonia

Ge, C., Fu, J., Chang, Y., Wang, L. (2011) „Factors associated with job satisfaction among Chinese community health workers: a cross-sectional study", BMC Public Health, 11:884, p. 1-13. https://doi.org/10.1186/1471-2458-11-884

Gregori, D., Napolitano, G., Scarinzi, C., Semerraro, A., Rosato, R., Pagano, E., Zigon, G., Gabassi, P. (2007) „Knowledge, practice and faith on Total Quality Management principles among workers in the Health Care System: Evidence from an Italian investigation", Journal of Evaluation in Clinical Practice, 15, p. 69-75. https://doi.org/10.1111/j.13652753.2008.00956.x

Ismyrlis,V., Moschidis, O., Tsiotras, G. (2015) „Critical sucess factors examined in ISO 9001:2008 - certified Greek companies using multidimensional statistics", International Journal of Quality \& Reliability Management, 32(2). https://doi.org/10.1108/IJQRM-07-2013-0117

Jarrett, J. E. (2016) „Total quality management (TQM) movement in public health“, International Journal of Quality \& reliability Management, 33(1), p. 25-41. https://doi.org/10.1108/IJQRM-12-2013-0193

Judeh, M. (2011) „An examination of the effect of employee involvement on teamwork effectiveness: an empirical study“, International Journal of Business and Management, 6(9), p. 202-209. https://doi.org/10.5539/ ijbm.v6n9p202

Juran, J. M., Godfrey, A. B. (1999) Juran's Quality Handbook, 5th Edition, McGraw-Hill, USA

Kanji, G. K. (2002) Measuring Business Excellence, Routledge Advances in management and Business Studies, New York, USA

Karia, N., Asaari, M. H. A. H. (2006) „The effects of total quality management practices on employees' work-related attitudes", The TQM Magazine, 18(1), p. 30-43. https://doi.org/10.1108/09544780610637677 
Kundu, S. C., Gahlawat, N. (2015) „Socially responsible HR practices and employees' intention to quit: The mediating role of job satisfaction", Human Resource Development International, 18(4), p. 1-20. https://doi.org/10.1080/1367886 8.2015.1056500

Kuo, T., Chang, T., Hung, K., Lin, M. (2009) „Employees' perspective on the effectiveness of ISO 9000 certification: A Total Quality Management framework", Total Quality Management and Business Excellence, 20(12), p. 1321-1335. https://doi.org/10.1080/14783360903250530

Lagrosen, Y., Backstrom, I., Lagrosen, S. (2007) „Quality management and health: a double connection“, International Journal of Quality \& Reliability Management, 24(1), p. 49 - 61. https://doi.org/10.1108/0265671071 0720321

Lazibat, T., Burčul, E., Baković, T. (2007) „Primjena sustava za upravljanje kvalitetom u hrvatskom zdravstvu“, Poslovna izvrsnost, 1(2), p. 31-44

Leatherman, S., Ferris, T.G., Berwick, D., Omaswa, F., Crisp, N. (2010) „The role of quality improvement in strengthening health systems in developing countries", International Journal of Quality in Health Care, 22(4), p. 237-243. https:// doi.org/10.1093/intqhc/mzq028

Liu, N., Liu, W. (2014) „The effects of quality management practices on employees' well-being“, Total Quality Management \& Business Excellence, 25(11-12), p. 1247-1261. https://doi.org/10.1080/14783363.2012.704285

Locke, E. A. (1976) The nature and causes of job satisfaction in Dunnette, M. D. Handbook of Industrial and Organizational Psychology (1st Ed.), Chicago. IL: Rand McNally (1976)

Mahmoud, A. H. (2008) „A study of nurses' job satisfaction: The relationship to organizational commitment, perceived organizational support, transactional leadership, transformational leadership, and level of education", European Journal of Scientific Research, 22(2), p. 286-295

Martensen, A., Gronholdt, L. (2001) „Using employee satisfaction measurement to improve people management: An adaption of Kano's quality types“, Total Quality Management, 12(7-8), p. 949-957. https://doi.org/10. 1080/09544120100000020

Matzler, K., Fuchs, M., Schubert, A. (2004) „Does Kano's Model apply?", Total quality and Business Excellence, 15(9), p. 1179-1198. https://doi.org/10.1080/1478336042000255569

Matzler, K., Renzl, B. (2007) "Assessing asymmetric effects in the formation of employee satisfaction", Tourism Management, 28, p. 1093-1103. https://doi.org/10.1016/j.tourman.2006.07.009

Mosadeghrad, A. M., Yarmohammadian, M. (2006) „A study of relationship between managers' leadership style and employees' job satisfaction", Leadership in Health Services, 19(2-3), p. 11-28. https://doi.org/10.1108/ 13660750610665008

Mosadeghrad, A. M., Ferlie, E., Rosenberg, D. (2008) „A study of relationship between job satisfaction, organizational commitment and turnover intention among hospital employee", Health Sevices Management Research, 21(4), p. 211-227. https://doi.org/10.1258/hsmr.2007.007015

Mosadeghrad, A.M.(2015) „Developing and validating a TQM management model for public health sector organisations“. The TQM Journal, 27(5), p. 544-564. https://doi.org/10.1108/TQM-04-2013-0051

Nikić, D., Arandjelović, M., Nikolić, M., Stanković, A. (2008) „Job satisfaction in health care workers“, Acta Medica Medianae, 47(4), p. 9-12

Ooi, K., Lee, V., Chong, A. Y., Lin, B. (2013) „Does TQM improve employees' quality of work life? Empirical evidence from Malaysia's manufacturing firms", Production Planning \& Control, 24(1), p. 72-89. https://doi.org/10.1080/0953728 7.2011.599344

Oshagbemi, T. (2000). Is lenght of serice related to the level of job satisfaction?, International Journal of Social Economics, 27(3), pp. 213-226. https://doi.org/10.1108/03068290010286546

Parveen, M., Maimani, K., Kassim, N. M. (2017) „A comparative study on job satisfaction between registered nurses and other qualified public health sector professionals", International Journal of Public health sector Management, 10(4), p. 238-242. https://doi.org/10.1080/20479700.2016.1265781 
Pisani, K. (2009) „Education as related to job satisfaction and health“, Psychology, p. 1-19

Prajogo, D., Cooper, B.K. (2010) „The effect of people-related TQM practices on job satisfaction: A hierarchical model", Production Planning and Control, 21(1), p. 26-35. https://doi.org/10.1080/09537280903239383

Priede, J. (2012) „Implementation of Quality Management System ISO 9001 in the world and its strategic necessity“, Procedia-Social and Behavioral Sciences, 58, p. 1466-1475. https://doi.org/10.1016/j. sbspro. 2012.09 .1133

Pupavac, D., Lipovača, S., Sečen, V. (2012). Zadovoljstvo zaposlenika poslom - čimbenik uspješnosti suvremenih poduzeća, Zbornik radova Međimurskog veleučilišta u Čakovcu, 2(3), p. 79-83.

Sadikoglu, E., Olcay, H. (2014) "The effects of Total Quality Management practices on performance and the reasons of and the barriers to TQM practices in Turkey", Advances in Decision Sciences, p. 1-17. https://doi.org/ $10.1155 / 2014 / 537605$

Selebi, C., Minnaar, A. (2007) „Job satisfaction among nurses in a public hospital in Gauteng", Curationis, p. 53-61. https:// doi.org/10.4102/curationis.v30i3.1102

Seo, Y., Ko, J., Price, J. L. (2004) „The determinants of job satisfaction among hospital nurses: model estimation in Korea“, International Journal of Nursing Administration, 41, p. 437-446. https://doi.org/10.1016/j. ijnurstu. 2003.11.003

Sivasankar, P. (2013) „Employees attitude towards the implementation of quality management systems with special reference to K. G. hospital, Coimbatore", International Journal of Management Research and Business Strategy, 2(4), p. $121-128$

SO GO SURVEY, https://www.sogosurvey.com/

Stoimenova, A., Stoilova, A., Petrova, G. (2014) „ISO 9001 certification for hospitals in Bulgaria: Does it help service?", Biotechnology \& Biotechnological Equipment, 28(2), p. 372-378. https://doi.org/10.1080 /13102818 .2014.915491

Sun, H., Hui, I. K., Tam, A. Y. K., Frick, J. (2000) "Employee involvement and quality management", The TQM Magazine, 12(5), p. 350-354. https://doi.org/10.1108/09544780010341969

Sur, H., Mumcu, G., Soylemez, D., Atli, Y., Idrim, C. (2004) „Factors affecting dental job satisfaction, evaluation and the health profession", The Haworth Press, 27, p. 152-164. https://doi.org/10.1177/0163278704264053

Sušanj Šulentić, T. (2014) „Istraživanje povezanosti interne komunikacijske klime sa zadovoljstvom poslom i lojalnošću zaposlenika", Tržište, 26(1), p. 59-76

Talasaz, Z. H., Saadoldin, S. N., Shakeri, M. T. (2014) „Job Satisfaction \& Job Performance among Midwives Working in Public health sector Centres of Mashhad, Iran", Journal of Midwifery \& Reproductive Health, 2(3), p.157-164

Talib, F., Rahman, Z., Azam, M. (2011) „Best practices of TQM implementation in health care settings“, Health Marketing Quarterly, 28(3), p. 232-252. https://doi.org/10.1080/07359683.2011.595643

Ugboro, I. O., Obeng, K. (2000) „Top management leadership, employee empowerment, job satisfaction and customer satisfaction in TQM organizations: an empirical study", Journal of Quality Management, 5, p. 247-272. https://doi. org/10.1016/S1084-8568(01)00023-2

Vouzas, F. (2007) „Investigating the human resources context and content on TQM, business excellence and ISO 9001:2000", Measuring Business Excellence, 11(3), p. 1-9. https://doi.org/10.1108/13683040710820728

Zabada, C., Rivers, P.A., Munchus, G. (1998) „Obstacles to the application of TQM in public health sector organizations“, Total Quality Management, 9(1), p. 57-66. https://doi.org/10.1080/0954412989261

Zardasht, P., Omed, S., Taha, S. (2020) „Importance of HRM policies on employee job satisfacion“, Black Sea Journal of Management anad Marketing, 1(1), p. 49-57. https://doi.org/10.47299/bsjmm.v1i1.15

Wagner, C., Gulacsi, L., Takacs, E., Outinen, M. (2006) „The implementation of quality management systems in hospitals: a comparison between three countries", BMC Health Services Research, 6(50), p. 1-11. https://doi.org/ 10.1186/14726963-6-50 
I. Škarica, A. Vrtodušić Hrgović: Employee attitudes on TQM implementation and job satisfaction... Zbornik Veleučilišta u Rijeci, Vol. 9 (2021), No. 1, pp. 187-209

Withanachchi, N., Handa, Y., Karandagoda, K. K. (2007) „TQM emphasizing 5-S principles: A breakthrough for chronic managerial constraints at public hospital in developing countries", International Journal of Public Sector Management, 20(3), p. 168-177. https://doi.org/10.1108/09513550710740580

Welikala, D., Sohal, A. S. (2008) „Total Quality Management and employees' involvement: A case study of an Australian organisation", Total Quality Management and Business Excellence, 19(6), p. 627-642. https://doi.org/ $10.1080 / 14783360802024440$ 
Prethodno priopćenje

https://doi.org/10.31784/zvr.9.1.12

Datum primitka rada: 1. 12. 2020.

Datum prihvaćanja rada: 18. 2. 2021.

\title{
STAVOVI ZAPOSLENIKA O IMPLEMENTACIJI TQM-A I ZADOVOLJSTVU POSLOM U SEKTORU JAVNOGA ZDRAVSTVA
}

\author{
Ivana Škarica \\ Dr. sc., voditelj Odjela za kvalitetu, Nastavni zavod za javno zdravstvo Primorsko-goranske županije, \\ Krešimirova 52a, 51000 Rijeka, Hrvatska; e-mail: ivanaskarica969@gmail.com
}

\section{Ana-Marija Vrtodušić Hrgović}

Dr. sc., izvanredna profesorica, Sveučilište u Rijeci, Fakultet za menadžment u turizmu i ugostiteljstvu, Primorska 42, p.p. 97, 51410 Opatija, Hrvatska; e-mail: anamariv@fthm.hr

\section{SAŽETAK}

Kvaliteta usluge u javnozdravstvenom sektoru važan je aspekt koji utječe na zadovoljstvo pacijenata. Naime, osigurati kvalitetu u javnom zdravstvu znači pružati zdravstvene usluge na pristupačan, siguran i učinkovit način, uz minimalan rizik i štetu za pacijente. Drugim riječima, to znači ispuniti potrebe pacijenata i nadmašiti njihova očekivanja. Stoga, kako bi pacijentima pružile kvalitetne i zadovoljavajuće usluge, mnoge javnozdravstvene organizacije implementiraju standarde kvalitete koji imaju mnoge prednosti, a među kojima se posebno ističe zadovoljstvo zaposlenika. Cilj ovog istraživanja bio je ispitati odnos zaposlenika u zavodima za javno zdravstvo sa implementiranim sustavom upravljanja kvalitetom, prema dimenzijama zadovoljstva poslom i njihovu percepciju razine provedbe TQM-a, s obzirom na sociodemografske karakteristike zaposlenika. Kako bi se to postiglo korištena je ANOVA za testiranje hipoteza i uturdivanje razlike između promatranih socodemografskih karakteristika s obzirom na dimenzije zadovoljstva poslom i primjenu načela TQM - a u istraživanju. Uz to, korelacijom je ispitana povezanost između ukupnog zadovoljstva poslom i percepcije primjene ukupnih načela TQM-a. Dobiveni rezultati sugeriraju da stupanj obrazovanja i radni staž značajno utječu na razlike u ocjeni među zaposlenicima, dok pozicija na poslu utječe u manjoj mjeri, tj. kod određenih dimenzija. Rezultati također ukazuju na korelaciju jakog intenziteta između ukupnog zadovoljstva poslom i ukupnih načela TQM-a. Istraživanje obuhvaća vrijedne smjernice za upravljanje zdravstvenim ustanovama budući dobiveni rezultati istraživanja ukazuju na načela kvalitete i dimenzije zadovoljstva poslom kojima su zaposlenici najviše, odnosno, najmanje zadovoljni, te samim time usmjeravaju uprave zdravstvenih ustanova na područja u kojima je potrebno provesti određene mjere za poboljšanje. Budući je istraživanje posebno usmjereno na zavode za javno zdravstvo, buduća istraživanja se mogu proširiti na način da obuhvate i druge javnozdravstvene ustanove poput bolnica, ali i privatnih klinika, kao i ostale sektore.

Ključne riječi: zaposlenici, zadovoljstvo poslom, zdravstveni sektor, načela kvalitete, socio-demografska obilježja, TQM 
